Georgia State University

ScholarWorks @ Georgia State University

Middle-Secondary Education and Instructional Department of Middle-Secondary Education and Technology Faculty Publications Instructional Technology (no new uploads as of Jan. 2015)

2011

\title{
Social Studies Preservice Teachers' Citizenship Knowledge and Perceptions of the U.S. Naturalization Test
}

\author{
Frans H. Doppen \\ Joseph R. Feinberg \\ Georgia State University, jfeinberg@gsu.edu \\ Carolyn O'Mahony \\ Ashley G. Lucas \\ Chara Haeussler Bohan \\ Georgia State University, cbohan@gsu.edu
}

See next page for additional authors

Follow this and additional works at: https://scholarworks.gsu.edu/msit_facpub

Part of the Elementary and Middle and Secondary Education Administration Commons, Instructional Media Design Commons, Junior High, Intermediate, Middle School Education and Teaching Commons, and the Secondary Education and Teaching Commons

\section{Recommended Citation}

Doppen, F., Feinberg, J., O'Mahony, C., Lucas, A., Bohan, C., Lipscomb, G., Ogawa, M. (2011). Social studies pre-service teachers' citizenship knowledge and perceptions of the U.S. naturalization test. Action in Teacher Education, 33(1), 81-93.

This Article is brought to you for free and open access by the Department of Middle-Secondary Education and Instructional Technology (no new uploads as of Jan. 2015) at ScholarWorks @ Georgia State University. It has been accepted for inclusion in Middle-Secondary Education and Instructional Technology Faculty Publications by an authorized administrator of ScholarWorks @ Georgia State University. For more information, please contact scholarworks@gsu.edu. 


\section{Authors}

Frans H. Doppen, Joseph R. Feinberg, Carolyn O'Mahony, Ashley G. Lucas, Chara Haeussler Bohan, George Lipscomb, and Masato Ogawa 
Social Studies Preservice Teachers' Citizenship Knowledge and Perceptions of the U.S.

Naturalization Test

\author{
Frans H. Doppen, Ohio University \\ Joseph R. Feinberg, Georgia State University \\ Carolyn O'Mahony, Oakland University \\ Ashley G. Lucas, Towson University \\ Chara Haeussler Bohan, Georgia State University \\ George Lipscomb, Furman University \\ Masato Ogawa, Indiana University - Kokomo
}

Correspondence concerning this paper should be sent to Dr. Frans H. Doppen, Ohio University, College of Education, 210 B McCracken Hall, Athens, OH 45701.

Address email to doppen@ohio.edu. 


\begin{abstract}
Teacher educators from six states invited their social studies methodology students to complete an abbreviated version of the U.S. Citizenship and Immigration Services (USCIS) Naturalization Test. The preservice teachers were also asked to share their conceptions of citizenship and evaluate the naturalization test. The findings from this study indicated that although this sample of preservice teachers had limited conceptions of citizenship, most were able to get a satisfactory score on the test. The authors discuss the implications of these results and suggest ways to broaden citizenship education in teacher preparation programs.
\end{abstract}

Keywords: citizenship, civics, naturalization, preservice teachers, social studies, teacher education 
Social Studies Preservice Teachers' Citizenship Knowledge and Perceptions of the U.S. Naturalization Test

The U.S. citizenship test is much more controversial than the average citizen and educator may realize. Implicit assumptions that are embodied in the citizenship test are seldom examined or researched. For example, much controversy surrounded the revisions of the United States Citizenship and Immigration Services (USCIS) Naturalization Study Guide (Preston, 2007). Applicants began taking the revised test on October 1, 2008, after this study was completed. In redesigning the exam, at a cost of \$6.5 million, USCIS received assistance from test development contractors, U.S. history and government scholars, and English as a Second Language experts (Preston, 2007; USCIS, 2006b). USCIS also sought input from a variety of stakeholders, including immigrant advocacy groups, citizenship instructors and District Adjudications Officers. The director of the U.S. Citizenship and Immigration Services believes the test " talks about what makes an American citizen"” and conservative groups believe the changes are an improvement (Preston, 2007). However, some of the groups that were consulted for the new exam, such as the Illinois Coalition for Immigrant and Refugee Rights, denounced the test as being irrelevant (Preston, 2007). Although this study concluded prior to the new version being released, the prior USCIS Naturalization Test was used as a pedagogical and evaluation tool to analyze preservice teachers' civic knowledge and perceptions.

Utilizing simulations is one relevant curricular approach advocated by the Center for Information and Research on Civic Learning and Engagement (CIRCLE, 2003). Thus, the USCIS Naturalization Test was simulated for preservice teachers to explore their knowledge and notions of citizenship. More importantly, participants reviewed the test items, and suggested question revisions in anticipation of the newly revised test. In doing so, they provided insights 
into their beliefs about citizenship. In other words, the USCIS Naturalization Test became a pedagogical tool for introducing notions of citizenship and citizenship education to preservice teachers.

This study provides a unique approach for considering what preservice social studies teachers should know and be able to teach about citizenship content knowledge and naturalization issues that immigrants face. The use of the citizenship test in this context raises questions about the extent to which future educators should understand the citizenship test and the requirements to become an American citizen. Thornton (2003) has pointed out that it is useful for social studies methods classes to discuss and distinguish between what to teach and how to teach. This distinction breaks down in practice. In social studies methodology classes, it seems imperative to find topics and devices that enable teacher educators to address important contemporary issues. In addition, such an examination may help preservice teachers think about what they will need to know if they really want to engage their future students in democratic practices.

Fewer than $25 \%$ of the more than 21 million people who have immigrated to the US since 1980 have become naturalized citizens (United States Census Bureau, 2009). Schools are the only institutions with both the mandate and the capacity to provide young people with opportunities to learn how to be citizens (CIRCLE, 2007). Unfortunately, efforts at teaching participatory democracy may be thwarted not only by the structures and hidden curricula of schools (Kubow, 1997), but also by the linguistic and socio-cultural differences between K-12 students and their teachers. This "demographic imperative" is often used as a rationale for multicultural teacher preparation programs (Lowenstein, 2009). Thus, modeling a real-world simulation of the citizenship test with preservice teachers provides a strong rationale for future 
teachers to enhance their citizenship knowledge and pedagogical practice. However, the task of educating future citizens becomes increasingly problematic when teachers themselves lack deeper levels of civic knowledge and perceptions. This research project utilizes the citizenship test as a litmus assessment of the civic knowledge and perceptions of good citizenship displayed by a multistate convenience sample of preservice teachers.

The USCIS Naturalization Test is a clear indication of what the U.S. government expects citizens to know. Yet, defining what citizens should know and how to assess what they actually know are challenges for both policymakers and teachers in their respective roles. According to Ladson-Billings (2005), citizenship can be conceptualized as membership in three communities: the legal, the political, and the social. Policies and practices at the federal, state, and local level, such as immigration laws, restrict admission to these communities. Although this simulation of the test provided an opportunity for discussion and debate about citizenship, future educators must understand that new immigrants are neither given a choice as to how to become legal citizens of the United States, nor the opportunity to reflect on conceptions of good citizenship ${ }^{1}$.

A variety of conceptions of good citizenship have been identified throughout the citizenship literature. Many educational researchers agree there is a spectrum of different types of citizens (e.g., Allen, 1996; Clark \& Case, 1997; Westheimer \& Kahne, 2004). For example, Westheimer and Kahne (2004) contrast and detail three broad conceptions (personally responsible, participatory, and justice oriented) for citizenship education that were surmised from the various program strategies and approaches to democratic education. They caution, however, that "obedience and patriotism" are not necessarily democratic goals and would also be rather desirable civic traits in a totalitarian regime. Indeed, some of the current citizenship education

\footnotetext{
${ }^{1}$ The new test includes one question that asks immigrants to list two ways in which they can participate in our democracy (USCIS, 2009).
} 
conceptions are "narrow and often ideologically conservative," and reflect "political choices that have political consequences" (Westheimer \& Kahne, 2004, p. 237). Thus, the good intentions of educators to facilitate citizenship education are not always realized and may not promote democratic principles.

\section{Background}

The majority of today's preservice teachers are members of the generation of young people described in the CIRCLE reports of 2003-2007. As the civic engagement of young people appears to decline, so has school-based citizenship education. Many factors contribute to the decline, such as the movement towards high-stakes testing, teachers' fear of criticism when discussing controversial issues, and the impact of budget cutbacks on civic education (CIRCLE, 2003; Miller, 2007). According to CIRCLE (2007), civic attitudes among youth have degenerated and young people are less interested in public affairs. In 2006, Lopez, Levine, Both, Keisa, Kirby, and Marcelo found that nearly $20 \%$ of young people, ages 15 to 25, were completely disengaged. Even though nearly $75 \%$ of the participants in their study indicated that they followed what was going on in government and public affairs at least some of the time, many had lost confidence in government, and their political knowledge was generally poor. In contrast, a comprehensive study of civic knowledge, attitudes, and experiences of ninth graders in the United States showed that the mean score on civic knowledge of U.S. students was significantly above the international mean (Hahn, 2001; Torney-Purta, Lehmann, Oswald, \& Schulz, 2001). Given these somewhat contradictory findings, the U.S. citizenship test can be used as an additional tool to broaden knowledge and perceptions of citizenship.

Unfortunately, many teachers appear ill-prepared to effectively deliver citizenship education. Two studies in the 1980s found that elementary preservice teachers were unprepared 
to explain to children how the American government works (Gilmore, 1988; Larkins, 1984). In a more recent study of an elementary education methods course, which focused on the intersection between patriotism and citizenship, Nash (2005) found that her preservice teachers faced factual as well conceptual challenges. Mistakes included being unable to consider perspectives beyond a two-sided polemic mode, equating patriotism with feeling love, respect, and loyalty, and demonstrating those emotions by saluting the flag. The preservice teachers had a limited understanding of tolerance, diversity, and multiculturalism. In addition, they failed to suggest that questioning governmental policies or actions could ever be considered an act of good citizenship (Nash, 2005).

Two decades ago, Giroux (1985) wrote about the disempowerment of teachers in the debates about educational quality and the nature of schooling. He argued that teacher educators frequently neglect the important need to have preservice teachers examine the causes of fundamental school problems. His study was not designed to determine the problems of civic education, but rather to explore how individual teachers can impact the quality of civic instruction. Similarly, the researchers for this study sought to identify a starting point for exploring how teacher educators might develop approaches or activities that will empower their graduates to create classroom environments focused on civic education.

\section{Design}

Typically, USCIS officers randomly select ten questions from a master list of 100 questions to orally examine a prospective citizen's civic knowledge. The seven researchers in this study administered an abbreviated version (50 questions) of the USCIS Naturalization Test to a convenience sample of preservice teachers in their respective social studies methods courses. 
Participants were asked to write responses to questions pertaining to the content of the test. Their responses were coded according to emerging patterns observed by the researchers.

The 211 participants included 116 elementary, 32 middle, and 63 high school social studies preservice teachers. One hundred sixty-nine participants $(80 \%)$ were undergraduate students, 42 participants (20\%) were graduate students. One hundred fifty participants (74\%) were under the age of 24, and 55 participants (26\%) were age 24 and older. Of the 156 participants under the age of 24,140 were undergraduate students while 16 were graduate students. Despite their different geographical locations, the participants' ethnic backgrounds were overwhelmingly Caucasian (96.7\%) while the remaining 3.3\% included five AfricanAmerican, one Hispanic, and one "Other" student. Participants were categorized according to the major focus of each methodology course. Due to differences in grade level and certification across the six states, the three categories of elementary, middle school and high school included some minor grade level overlaps.

A central focus of the study was to get a sense of social studies preservice teachers' performance on and response to the citizenship test. Given the differing numbers of participants in each category across the universities, differing course trajectories in each institution prior to the methods course, and non-centralized scoring of the tests, the data did not lend itself to comparison across states. However, several patterns emerged from the data after analysis across grade level groups.

\section{Passing the Test}

Assessing an individual's potential for being a knowledgeable citizen is challenging. Nevertheless, thousands of immigrants every year are expected to correctly answer the USCIS Naturalization Test questions. Not surprisingly, undergraduate preservice teachers preparing to 
teach social sciences in high schools scored the highest on the test ( $91 \%$ correct) followed by middle school (77\% correct). Future elementary school teachers scored the lowest (62\% correct).

Three questions were especially challenging for all preservice teachers as $50 \%$ or more of any of the three participant groups were not able to answer these questions correctly. The questions asked them to identify their state Senators, the total number of representatives in the U.S. House of Representatives, and the year in which the U.S. Constitution was adopted. Two questions that posed a challenge for more than $50 \%$ of the elementary and middle, but not high, school preservice teachers asked for the length of a U.S. Senator's term and the name of the current Chief Justice of the U.S. Supreme Court. Less than one-fourth (23\%) of the elementary and half (48\%) of the middle school preservice teachers knew the length of a Senator's term. Furthermore, less than one-twentieth (3\%) of the elementary and fewer than one-fourth $(23 \%)$ of the middle school preservice teachers knew that John Roberts is the current Chief Justice.

Identifying the two U.S. Senators from their state was the only one out of all 50 questions for which there was a noticeable change in the general response pattern as more than one-fourth $(28 \%)$ of the elementary preservice teachers answered the question correctly compared to fewer than one-fifth (19\%) of the middle school preservice teachers. A possible reason for this anomaly could be the expanding horizons scope and sequence of the elementary social studies curriculum. Regardless of their home state, preservice teachers in elementary field placements with fourth graders or younger are more likely to be talking about local and state politicians than about national ones.

More than $50 \%$ of the elementary preservice teachers were unable to correctly answer more than 17 out of the 50 questions. In addition to the five questions described above, the elementary preservice teachers in this study struggled with 12 additional questions about: the 
purpose of the U.S. Constitution; the length of a U.S. Representative's term; the purpose of the executive and judiciary branch; defining the Bill of Rights; the line of succession should the President and Vice-President die; the number of justices on the Supreme Court; the basic belief underlying the U.S. Declaration of Independence; the role of the Cabinet; the name of the building where the U.S. Congress meets; and how often a member of the U.S. Congress can be re-elected.

\section{Reflecting on the Test}

The participants' perceptions of good citizenship were assessed by analyzing their responses to four questions regarding the content of the citizenship test. Thus, the 211 participants were asked to respond to the following written survey that was administered by the researchers: 1) Explain whether you think the questions on the citizenship test represent what every immigrant applying for citizenship should know, 2) Explain whether you think the citizenship test represents what every American citizen born in this country should know, 3) The U.S. Citizenship and Immigration Services is currently revising the citizenship test. Explain, if you were revising this version of the citizenship test, which questions, if any, would you delete and/or change, and 4) The U.S. Citizenship and Immigration Services is currently revising the citizenship test. Explain, if you were revising this version of the citizenship test, which questions, if any, would you add?

Given the uneven demonstration of citizenship knowledge on the test as a whole or on some specific items, one might expect the preservice teachers in this study, especially those in the elementary group, to perceive the nature of the questions that were asked of prospective fellow citizens as being narrow and irrelevant to full participation. For instance, the test did not ask immigrants to determine what types of discrimination are illegal in the U.S., yet legal and 
social equality are fundamental constitutional principles that historically differentiate the U.S. from many other countries. Similarly, as an assessment issue, one might reasonably have expected the preservice teachers in this study to suggest that questions on such a test should elicit evidence of the attributes of a good citizen. Yet, when asked if they thought the questions on this test represented what every immigrant applying for citizenship should know, they generally agreed (59\% yes, $39 \%$ no, $2 \%$ no response). This result is not as simple to evaluate as the numbers may suggest. When asked about changing questions for a revised naturalization test, only $34 \%$ of respondents agreed unconditionally with the statement that the questions represent what every immigrant applying for U.S. citizenship should know. Conditional responses tended to focus on issues of fairness contending that most Americans by birth would not be able to answer many of the questions.

Many of the preservice teachers who rejected the test as an effective assessment of what immigrants should know when applying for citizenship (i.e., the "no" responses) also claimed that it was unfair to expect immigrants to know more than native citizens. Individuals suggested that it was more important to know the laws, be able to speak English, or to be patriotic and loyal to the United States. One preservice teacher concluded:

Why does a new citizen need to know all this stuff? [Is the USCIS] testing for ambition? Ambitious people will study, practice, do well; lazy people will not study, not do well? Literacy? Ability to follow societal norms - follow directions etc? They are testing for something besides people's knowledge of these ideas.

When the preservice teachers were asked whether the naturalization test was a good assessment of what citizens born in the United States should know, an overwhelming $81 \%$ of the preservice teachers agreed, yet only $49 \%$ did so unconditionally. Conditional "yes" responses 
were frequently colored by an individual's performance on the test. For example, a number of participants wrote apologetic comments about and explanations of how one learns facts in school and then forgets them, or how the majority of Americans do not know these facts. Others said it is more important to know political structures instead of the exact dates of historical events. A number of students who disagreed with the content of the test were vehement about how poorly the test questions assessed one's potential for being a good citizen.

When asked what questions they would eliminate from the test and what they would add, the preservice teachers had surprisingly few suggestions. However, the questionnaire was given during a class session so there was limited class time for highly reflective written responses. Some students were concerned about questions that could elicit a number of ostensibly correct responses, e.g. the purpose of the Constitution.

When students reflected on the questions that were most commonly missed or answered incorrectly, there were individuals who suggested eliminating questions about the number of Senators or Representatives and the nature of terms and term limits. In most groups, individuals suggested eliminating questions they perceived as too specific, pertaining to trivial details about the flag, holidays, and history, and suggested, for instance, that it is more important for citizens to understand the purpose of the Declaration of Independence than to know who wrote it. Others suggested that the questions were culturally biased. One participant responded, "It seems like history should not be limited to Jefferson's writing the Declaration or Lincoln's Emancipation Proclamation. [It is a] very white, Anglo-Saxon exam." Yet other preservice teachers challenged the need for any questions about U.S. history. They proposed that it is more important for citizens to know how the government works than requiring them to know when documents were signed and what holidays the colonists celebrated. 
As stated earlier, when asked how they would revise the citizenship test, $34 \%$ of the preservice teachers had no suggestions for change at all. Suggestions from the other $66 \%$ included the idea that immigrants should know about their rights, state-level issues, and current events in the country. A number of them stated that there should be more of a focus on exploring why applicants wish to become citizens. They would have liked to added questions that assess whether an applicant is "cognitively able" (including being able to speak English) and intent on becoming a good, patriotic citizen (see Chebium, 2000). One preservice teacher wrote, "I would add some questions that make you tell how you really feel about the U.S. to me and how you would be loyal." Some suggested adding questions that spoke to an immigrant's ability to assimilate. They would prefer to ask questions that measure an applicant's grasp of American ideals, beliefs, and culture. Another preservice teacher stated, "I might ask some questions about cultural dynamics of the melting pot theory that is supposed to be America." One more respondent suggested adding questions that would assess “a person's ability to thrive in the U.S., e.g. laws, the tax system etc."

Perhaps because of the nature of the question, few individuals commented on the validity of the test in assessing a person's potential value as a citizen of the United States of America. Only two individuals spoke to this issue, suggesting that instead of taking a test, applicants should be required to undertake a service project that demonstrates their desire to become a citizen.

\section{Implications for Teacher Education}

Although the secondary and middle level participants scored reasonably well on the citizenship test, the elementary preservice teachers' poor results reaffirm some of the previously summarized research findings (Gilmore, 1988; Larkins, 1984; Nash, 2005). In particular, Nash 
(2005) highlighted the narrow conceptions of preservice teachers. The preservice teachers in this study did not question the content validity of the test, even when faced with their own failing scores, and subscribed to the limited conception of personally responsible citizenship (Doppen, Misco, \& Patterson, 2008; Westheimer \& Kahne, 2004).

For many teacher educators, the preservice teachers' scores on the USCIS Naturalization Test and their responses to the follow-up questions will be both expected and disconcerting because, apart from being unable to recall so-called citizenship knowledge (especially the respondents preparing to be elementary school teachers), these future teachers most likely regard themselves and each other as good citizens. Despite the poor performance of some of these participants on the test, they nonetheless may well be the kind of citizens we would want living in our communities. Yet, this study's preservice teachers did not demonstrate broad conceptions of citizenship. The overwhelming majority of responses were not indicative of participatory, let alone justice oriented perspectives (Abowitz \& Harnish, 2006; Banks, McGee Banks, Cortes, Hahn, \& Merryfield, 2005; Ladson-Billings, 2005; Lynch, 1992).

The majority of the responses and suggestions for change failed to capture the importance of action in the world's oldest participatory democracy. Their statements fell short of being able to evaluate the extent the USCIS Naturalization Test encourages prospective citizens to participate in the public decision-making process (Allen, 1996; Clark \& Case, 1997; Westheimer \& Kahne, 2004). Nonetheless, it seems important that preservice teachers, who will soon be entrusted with educating children about how to participate in a democratic system, be aware that willing and informed participation in real-world problem-solving and policymaking is essential for maintaining a healthy democracy. 
Few of the preservice teachers in this study demonstrated some cognition of the value of civic participation and leadership. In their study of rural school age students, Martin and Chiodo (2007) argued that students function as citizens within environmental and age-appropriate limitations. Within school settings, students participate in many curricular and extracurricular activities that directly and indirectly serve to prepare them as citizens. Yet, this may well not be accomplished despite good intentions by teachers to prepare tomorrow's citizens imbued with participatory democratic principles.

The USCIS Naturalization Test provides a powerful pedagogical approach for teachers and students to explore issues related to citizenship and immigration as well as conceptions of good citizenship. Social studies teachers and teacher educators should consider asking their students to explore the concept of good citizenship. Ideally, such a discussion would engage them in synthesizing the various conceptions of citizenship and encourage a rethinking of citizenship to include a participatory and/or justice oriented approaches. The new citizenship test seeks to address some of the preceding concerns. While only a few of the participants in this study recognized the need to revise the citizenship test to include a broader conception of what it means to be a good citizen, most preferred the assimilation focus of the test that supports a personally responsible citizen (Westheimer \& Kahne, 2004).

Thornton (2001, 2003) has argued that liberal arts professors, who often teach the bulk of teacher preparation course work, seldom think of themselves as teacher educators, whereas education school professors tend to define their task as limited to pedagogy. Furthermore, he has suggested that the solution for improving the knowledge base of teachers does not lie in increasing the number of content courses preservice teachers take, but rather in blurring the lines between subject matter and professional education. Preservice teachers should be required to 
take courses based on what they will be expected to teach. Such an approach would allow teacher preparation programs to better prepare their candidates to teach about and for citizenship.

The findings in this study with regard to social studies preservice elementary and middle teachers point to the potential of and need for conversations across subject areas in teacher education programs regarding the qualities and knowledge base for teaching citizenship K-8. Being able to construct a persuasive argument is a crucial tool for participating in civic discourse. Compared to such aptitudes, knowing the year when the U.S. Constitution was ratified may seem unimportant, even trivial. What is not trivial is the type of change that might happen if system-wide efforts were made to increase and improve the quality of young people's civic engagement, starting with teacher preparation programs.

Future studies should examine the new USCIS Naturalization Test and determine whether its creators have actually achieved their goal of developing a "meaningful test" (U.S. Citizenship and Immigration Services, 2006a). Additional studies should also interview and examine whether immigrants and recently naturalized citizens have different perspectives on the citizenship test and the nature of citizenship. Finally, more research on preservice teachers' knowledge and notions of citizenship is necessary to further clarify the findings from this study. 


\section{References}

Abowitz, K. K., \& Harnish, J. (2006). Contemporary discourses of citizenship. Review of Educational Research, 76 (4) 653-690.

Allen, R. F. (1996). Introduction: What should we teach in social studies? And why? In B. G. Massialas, \& R. F. Allen (Eds.), Crucial issues in teaching social studies K-12. Belmont, CA: Wadsworth.

Banks, J. A., McGee Banks, C. A., Cortes, C. E., Hahn, C. L., Merryfield, M. M., Moodley, K. A., Murphy-Shigamatsu, S., Osler, A., Park, C., \& Parker, W. C. (2005). Democracy and diversity: Principles and concepts for educating citizens in a global age. Seattle, WA: Center for Multicultural Education.

Center for Information and Research on Civic Learning and Engagement (CIRCLE). (2007). The civic mission of schools: 2003-2007. New York, NY: Carnegie Corporation of New York.

Chebium, J. (2000, July 18). Disabled woman's family says INS denial of citizenship is discriminatory. CNN.com. Retrieved from http://archives.cnn.com/2000/LAW/07/18/citizenship.ins.suit/index.html

Clark, P., \& Case, R. (1997). Four purposes of citizenship education. In R. Case, \& P. Clark (Eds.), The Canadian anthology of social studies: Issues and strategies for teachers (pp. 17-27). Burnaby, BC: Simon Fraser University Field Relations.

Doppen, F., Misco, T., \& Patterson, N. (2008). The state of K-12 social studies instruction in Ohio. Social Studies Research and Practice, 3(3), 1-25. 
Faulks, K. (2006). Rethinking citizenship education in England: Some lessons from contemporary social and political theory. Education, Citizenship and Social Justice, 1, $123-140$.

Gilmore, A. C. (1988). Preservice elementary education majors knowledge of American government (Report No. SO 019 805). Atlanta, GA: Mercer University.

Giroux, H. A. (1985). Teachers as transformative intellectuals. Social Education, 49, 376-379.

Hahn, C. (2001). Civic knowledge, attitudes, and experiences of ninth graders in the United States. Results of the IEA civic education study. Washington, DC: U.S. Department of Education.

Kubow, P. K. (1997, April). Citizenship education for the $21^{\text {st }}$ century: Insights from social studies teacher preparation students in three countries. Paper presented at the annual meeting of the American Education Research Association, Chicago, IL.

Ladson-Billings, G. (2005). Differing concepts of citizenship: Schools and communities as sites of civic development. In N. Noddings (Ed.), Educating citizens for global awareness (pp. 69-80). New York: Teachers College Press.

Larkins, A. C. (1984, November). Preservice teachers' knowledge of social studies content in primary grades. Paper presented at the annual meeting of National Council for the Social Studies, Washington, DC.

Lopez, M. H., Levine, P., Both, D., Keisa, A., Kirby, E. \& Marcelo, K. (2006). The 2006 civic and political health of the nation: A detailed look at how youth participate in politics and communities. College Park, MD: Center for Information and Research on Civic Learning and Engagement. 
Lowenstein, K. L. (2009). The work of multicultural teacher education: Reconceptualizing white teacher candidates as learners. Review of Educational Research 79, 163-196.

Lynch, J. (1992). Education for citizenship in a multicultural society. New York, NY: Cassel.

Martin, L. A. \& Chiodo, J. J. (2007). Good citizenship: What students in rural schools have to say about it. Theory and Research in Social Education, 35(1), 112-134.

Miller, J. J. (2007, April). Can political participation be taught? Education Week, 26, 36.

Nash, M. A. (2005). How to be thankful for being free: Searching for a convergence of discourses on teaching patriotism, citizenship, and United States history. Teachers College Record, 107, 214-240.

National Council for the Social Studies. (1994). Expectations of excellence: Curriculum standards for social studies. Washington, DC: Author.

Thornton, S. (2001, November). Subject matter in social studies teacher education. Paper presented at the annual meeting of the National Council for the Social Studies, Washington, DC.

Thornton, S. (2003, April). What counts as subject matter knowledge for teaching? Paper presented at the annual meeting of the American Education Research Association, Chicago, IL.

Torney-Purta, J., Lehmann, R., Oswald, H., \& Schulz, W. (2001). Citizenship and education in twenty-eight countries: Civic knowledge and engagement at age fourteen. Amsterdam, The Netherlands: The International Association for the Evaluation of Educational Achievement.

United States Census Bureau. (2009). Foreign born profiles by citizenship status. Retrieved from http://www.census.gov/population/www/socdemo/foreign/STP-159-2000tl.html 
U.S. Citizenship and Immigration Services (2006a). Fact sheet: USCIS naturalization test redesign. Washington, DC: Author. Retrieved from http://www.uscis.gov/portal/site/uscis

U.S. Citizenship and Immigration Services (2006b). Press release: USCIS issues, questions and anwers for the new pilot naturalization exam. Washington, DC: Author.

United States Citizenship and Immigration Services (2007). Redesigned Naturalization Test. Retrieved from http://www.uscis.gov/portal/site/uscis

United States Citizenship and Immigration Services (2009). The U.S. Naturalization Practice Test. Retrieved from http://www.uscis.gov

Westheimer, J., \& Kahne, J. (2004). What kind of citizen: The politics of educating for democracy. American Educational Research Journal, 41(2), 237-269. 